\title{
Mitigation of Chromium Contamination by Copper-ZVI Bimetallic Particles
}

\author{
Rama Pal'; Sudhakar M. Rao ${ }^{2}$; and S. Sivachidambaram ${ }^{3}$
}

\begin{abstract}
Soil and water pollution by chromium is a major environmental concern. Although existence of chromium in the $\mathrm{Cr}^{3+}$ state is considered benign, its presence in the $\mathrm{Cr}^{6+}$ state poses an environmental concern. Hence, reduction of chromium(VI) to chromium(III) is considered as a satisfactory environmental solution to mitigate chromium contamination. The oxidation of a metal substrate can be enhanced by depositing a small amount of nobler metal on its surface. The present study thus examines the efficiency of chromium(VI) reduction upon deposition of copper (oxidation potential: $-0.34 \mathrm{~V}$ ) on the surface of zero-valent iron (ZVI) (oxidation potential: $0.04 \mathrm{~V}$ ) particles. Batch experiments and $\mathrm{pH}$ and Eh measurements revealed that presence of copper loading on ZVI particles increases the efficiency of chromium(VI) reduction by 11-233\% in relation to the uncoated ZVI particles owing to enhanced electron activity and release of hydroxyl ions that converted chromium(VI) to mixed $\mathrm{Fe}-\mathrm{Cr}$ oxide. The chromium(VI) reduction was accomplished in periods ranging from 60 to $240 \mathrm{~min}$ in the batch experiments and obeyed the pseudo first- or second-order kinetics. DOI: 10.1061/(ASCE)HZ.2153-5515.0000169. (c) 2013 American Society of Civil Engineers.
\end{abstract}

CE Database subject headings: Metals (chemical); Chromium; Abatement and removal; Particles; Copper.

Author keywords: Bimetals; Contaminant; Hexavalent chromium; Removal.

\section{Introduction}

Chromium generally occurs in the $\mathrm{Cr}^{6+}$ and $\mathrm{Cr}^{3+}$ oxidation states (Palmer and Puls 1994; Proctor et al. 1997; Gui et al. 2009). Waterinsoluble chromium(III) compounds are not considered health hazards, whereas chromium(VI) ions are toxic in nature (Barceloux and Barceloux 1999; Jacobs and Testa 2005). Chromium(III) ions predominantly occur as $\mathrm{Cr}^{3+}$ at $\mathrm{pH}<3.5$, and increasing $\mathrm{pH}$ tends to hydrolyze the ions (Rai et al. 1987; Palmer and Puls 1994). The nontoxic nature of chromium(III) ions and their ease of hydrolysis in the $\mathrm{pH}$ range of $4.5-10$ renders reduction of chromium(VI) to chromium(III) as a satisfactory environmental solution (Erdem et al. 2004).

A permeable reactive barrier composed of granular iron has been constructed to remediate hexavalent chromium - contaminated groundwater (Blowes et al. 1999). The oxidation of $\mathrm{Fe}^{0}$ to $\mathrm{Fe}^{3+}$ ions facilitates reduction of chromium(VI) to chromium(III) state. Chromium(III) ions in turn precipitate as $\mathrm{Cr}(\mathrm{OH})_{3}$ or coprecipitate as mixed Fe-Cr hydroxide (Eary and Rai 1988; Puls et al. 1999; Powell et al. 1995; Blowes et al. 1997). The precipitates formed by hydrolysis of chromium(III) and iron(III) ions tend to block pathways for electron transfer from interior of zero-valent iron (ZVI) particles, thereby affecting the efficiency of chromium(VI) removal

${ }^{1}$ Former Research Associate, Centre for Sustainable Technologies, Indian Institute of Science, Bangalore 560012, India.

${ }^{2}$ Professor, Dept. of Civil Engineering and Chairman, Centre for Sustainable Technologies, Indian Institute of Science, Bangalore 560012, India (corresponding author). E-mail: msrao@civil.iisc.ernet.in

${ }^{3}$ Research Student, Centre for Sustainable Technologies, Indian Institute of Science, Bangalore 560012, India.

Note. This manuscript was submitted on May 28, 2011; approved on November 8, 2012; published online on November 10, 2012. Discussion period open until December 1, 2013; separate discussions must be submitted for individual papers. This paper is part of the Journal of Hazardous, Toxic, and Radioactive Waste, Vol. 17, No. 3, July 1, 2013. (C) ASCE, ISSN 2153-5493/2013/3-181-186/\$25.00.
(Alowitz and Scherer 2002; Melitas and Farrell 2002; Lo et al. 2006; Hu et al. 2010).

Depositing a small amount of nobler metal (Pd, Pt, Ag, Ni, and $\mathrm{Cu}$ ) on the surface of ZVI particles was observed to accelerate the degeneration rate of nitrates and chlorinated organic compounds (Muftikian et al. 1995; Grittini et al. 1995; Cheng et al. 1997; Kim and Carraway 2000; Lin et al. 2004; Liou et al. 2005). $\mathrm{Hu}$ et al. (2010) observed that coating ZVI particles with copper enhanced the chromium(VI) removal efficiency of ZVI. According to Liou et al. (2005), when iron is coated with nobler metal, a relative potential difference drives the electron from iron particles; these electrons are accepted by adsorbed hydrogen ions to form adsorbed atomic hydrogen, and the hydrogen gas formed by combination of adsorbed hydrogen atoms contributes to the reduction process. Hu et al. (2010) observed that coating the ZVI (oxidation potential to $\mathrm{Fe}^{3+}: 0.04 \mathrm{~V}$ ) with copper (oxidation potential to $\mathrm{Cu}^{2+}:-0.34 \mathrm{~V}$ ) resulted in threefold to ninefold higher chromium(VI) removal per unit mass of ZVI particles. The present paper extends the work of $\mathrm{Hu}$ et al. (2010) on chromium(VI) reduction by $\mathrm{Cu}-\mathrm{ZVI}$ bimetallic particles by examining the kinetics of chromium(VI) reduction and the influence of variations in compositional parameters [solids:solution ratio, initial chromium(VI) concentration]. Further, the magnitude of copper deposition on the surface of ZVI particles is enhanced by performing the bimetallic particle preparation at an elevated temperature of $60^{\circ} \mathrm{C}$.

\section{Materials and Methods}

Analytical reagent-grade $\mathrm{K}_{2} \mathrm{Cr}_{2} \mathrm{O}_{7}, \mathrm{CuCl}_{2} \cdot 2 \mathrm{H}_{2} \mathrm{O}$, and $\mathrm{H}_{2} \mathrm{SO}_{4}$ were used in the studies. Zero-valent iron $(99.6 \%$, electrolytic, and finer than \#75 mesh) was obtained from J. T. Baker Chemicals (Mumbai, India). The specific gravity and surface area (determined by the BET method) of ZVI particles were determined to be 7.5 and $0.56 \mathrm{~m}^{2} / \mathrm{g}$, respectively.

The 10-, 30-, and 50-mg/L nonbuffered chromium(VI) ion solutions were prepared by suitable dilutions of $100-\mathrm{mg} / \mathrm{L}$ stock 
Table 1. Copper Consumed and Release of Fe Ions during Preparation of Bimetallic Particles

\begin{tabular}{|c|c|c|c|c|c|}
\hline $\begin{array}{l}\text { Mass of } \mathrm{ZVI}(\mathrm{g}) \\
\text { in } \mathrm{CuCl}_{2} \text { solution }\end{array}$ & $\begin{array}{c}Q_{\mathrm{Cu} / \mathrm{Fe}} \\
\text { (percentage) }\end{array}$ & $\begin{array}{l}\text { Volume of } \mathrm{CuCl}_{2} \\
\text { solution }(\mathrm{mL})\end{array}$ & $\begin{array}{l}\text { Initial amount of copper present } \\
\text { in } \mathrm{Cu} \text { solution }(\mathrm{mg})\end{array}$ & $\begin{array}{c}\text { Residual copper } \\
\text { concentration }(\mathrm{mg} / \mathrm{mL})\end{array}$ & $\begin{array}{l}\text { Amount of Fe ions released } \\
\text { in solution }(\mathrm{mg})\end{array}$ \\
\hline \multirow[t]{3}{*}{0.5} & 1 & 2.5 & 5 & 0.002 & 4.25 \\
\hline & 5 & 12.5 & 25 & 0.0024 & 20.43 \\
\hline & 8 & 20 & 40 & 0.003 & 33 \\
\hline \multirow[t]{3}{*}{1} & 1 & 5 & 10 & 0.003 & 8.46 \\
\hline & 5 & 25 & 50 & 0.003 & 45.9 \\
\hline & 8 & 40 & 80 & 0.003 & 70.7 \\
\hline \multirow[t]{3}{*}{2} & 1 & 10 & 20 & 0.003 & 15.22 \\
\hline & 5 & 50 & 100 & 0.003 & 90.1 \\
\hline & 8 & 80 & 160 & 0.003 & 120.5 \\
\hline
\end{tabular}

solution using $\mathrm{N}_{2}$-purged ultrapure water (electrical conductivity $=$ $0.055 \mu \mathrm{S} / \mathrm{cm}$ ). To examine chromium(VI) reduction under alkalinity buffered groundwater conditions, $5-\mathrm{mg} / \mathrm{L}$ chromium(VI) solution buffered with $250-\mathrm{mg} / \mathrm{L} \mathrm{HCO}_{3}^{-}$(bicarbonates) was prepared $(\mathrm{pH}=7.9)$ on the basis of the concentration level reported by Ramesh et al. (2012) for chromium(VI)-contaminated groundwater in an industrial locality of Bangalore, India.

\section{Preparation of Copper-Loaded ZVI Particles}

A $2,000 \mathrm{mg} / \mathrm{LCu}^{2+}$ solution was prepared by dissolution of copper chloride salt in $\mathrm{N}_{2}$-purged ultrapure water. Known mass $[0.5,1$, and $2 \mathrm{~g}$ (Table 1)] of acid-activated ZVI particles were agitated with definite volumes [2.5-80 mL (Table 1)] of $2,000-\mathrm{mg} / \mathrm{LCu}^{2+}$ solution at $60^{\circ} \mathrm{C}$ for $15 \mathrm{~min}$ to achieve $Q_{\mathrm{Cu} / \mathrm{Fe}}$ ratios of 1,5 , and $8 \%$ on a dry mass basis, where $Q_{\mathrm{Cu} / \mathrm{Fe}}$ is defined as (Hu et al. 2010)

$$
Q_{\mathrm{Cu} / \mathrm{Fe}}=\operatorname{mass}_{\mathrm{Cu}} / \operatorname{mass}_{\mathrm{Fe}} \times 100 \%
$$

After equilibration, the suspensions were filtered, washed twice with $\mathrm{N}_{2}$-purged ultrapure water, and dried in a vacuum desiccator for $24 \mathrm{~h}$

\section{Batch Experiments}

Batch experiments were performed by agitating $2 \mathrm{~g}$ of ZVI or 0.5 , 1 , or $2 \mathrm{~g}$ of $\mathrm{Cu}-\mathrm{ZVI}$ bimetallic particles with $100 \mathrm{~mL}$ of nonbuffered chromium(VI) solutions $(10,30$, or $50 \mathrm{mg} / \mathrm{L})$ and buffered (with $250-\mathrm{mg} / \mathrm{LHCO}_{3}^{-}$ions) chromium(VI) solution $(5 \mathrm{mg} / \mathrm{L})$ using a wrist-action shaker at ambient temperature $\left(27 \pm 1^{\circ} \mathrm{C}\right)$. Care was taken to leave no headspace between the solution and the screw cap of the polytetrafluorethylene bottle to prevent oxygen from entering the solution. Solutions were sampled at regular time intervals up to $360 \mathrm{~min}$; the withdrawn samples were immediately subjected to $\mathrm{pH}$ and Eh measurements. After measurement of $\mathrm{pH}$ and Eh values, the samples were filtered through a $0.22-\mu \mathrm{m}$ membrane and subjected to chemical analysis.

\section{Analytical Methods}

The total chromium $\left(\mathrm{Cr}^{6+}\right.$ and $\left.\mathrm{Cr}^{3+}\right)$, copper, and iron concentrations in the filtrates were determined by atomic absorption spectrometer. The chromium(VI) concentration in the filtrate was measured by the 1,5-diphenylcarbazide method using ultraviolet (UV) visible spectrophotometer (measuring wavelength $=540 \mathrm{~nm}$ ). The chromium(III) concentration in the filtrate was obtained as chromium $(\mathrm{III})=$ total chromium $-\operatorname{chromium}(\mathrm{VI})$.

\section{Results and Discussion}

\section{Characterization of Copper-ZVI Specimens}

Fig. 1 presents the X-ray diffraction (XRD) pattern of ZVI. Major peaks corresponding to $\mathrm{Fe}^{0}\left(2 \theta=44.7\right.$ and $\left.82.4^{\circ}\right), \mathrm{Fe}_{2} \mathrm{O}_{3}(\mathrm{~s})$, and $\mathrm{Fe}_{3} \mathrm{O}_{4}(\mathrm{~s})\left(2 \theta=35.5^{\circ}\right)$ are identified. Oxides of iron form because of oxidation reactions occurring on the ZVI surface. The bimetallic particle preparation adopted in the present study differs from the procedure of $\mathrm{Hu}$ et al. (2010) in that ZVI in that study had been equilibrated with 1,000-mg/L copper chloride solution at room temperature. The higher equilibration temperature employed in the present study increased copper deposition, as evidenced by the marginal [0.3-0.005 mg/L (Table 1)] residual copper ion concentrations in the copper solution after equilibration. Comparatively, $\mathrm{Hu}$ et al. (2010) observed much higher residual copper concentrations of $<10 \mathrm{mg} / \mathrm{L}$, despite employing a less concentrated copper solution $(1,000 \mathrm{mg} / \mathrm{L})$. The increase in mass of Fe ions released in response to increase in $Q_{\mathrm{Cu} / \mathrm{Fe}}$ ratio (at given mass of ZVI particles) in Table 1 also implies enhanced reduction of copper ions and their subsequent deposition on the surface of ZVI particles.

Fig. 2(a) presents the XRD pattern of bimetal particles with $Q_{\mathrm{Cu} / \mathrm{Fe}}=8 \%$. Besides the $\mathrm{Fe}^{0}$ and $\mathrm{Fe}$ oxides peaks (identified in Fig. 1), $\mathrm{Cu}^{0}\left(2 \theta=43.7^{\circ}\right)$ reflection appears in the XRD pattern. Figs. 3( $\mathrm{a}$ and $\mathrm{b}$ ) compare the scanning electron micrographs of ZVI particles before and after copper deposition ( $2 \mathrm{~g}$ of ZVI agitated with $80 \mathrm{~mL}$ of $2,000 \mathrm{mg} / \mathrm{L} \mathrm{Cu}$ solution, $Q_{\mathrm{Cu} / \mathrm{Fe}}=8 \%$ ). The micrograph in Fig. 3(a) shows that ZVI occurs as discrete particles with smooth particle surfaces. The smooth surfaces of the ZVI particles appear eroded after copper deposition and exhibit growth of $<2-\mu$ m-sized precipitates [Fig. 3(b)]. Comparison of XRD patterns in Figs. 1 and 2(a) indicate that the intensities of $\mathrm{Fe}_{2} \mathrm{O}_{3}(\mathrm{~s})$ and $\mathrm{Fe}_{3} \mathrm{O}_{4}(\mathrm{~s})\left(2 \theta=35.5^{\circ}\right)$ peaks appear stronger after copper deposition [Fig. 2(a)]. The precipitates on the ZVI particles in Fig. 3(b) are

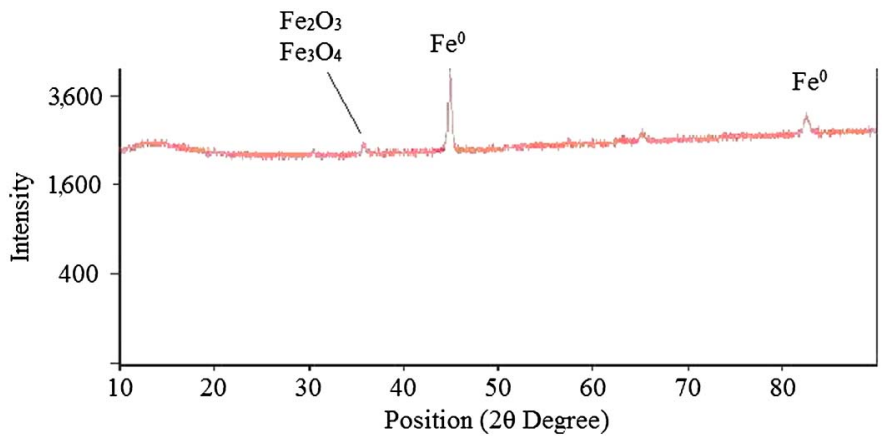

Fig. 1. XRD pattern of ZVI particles 

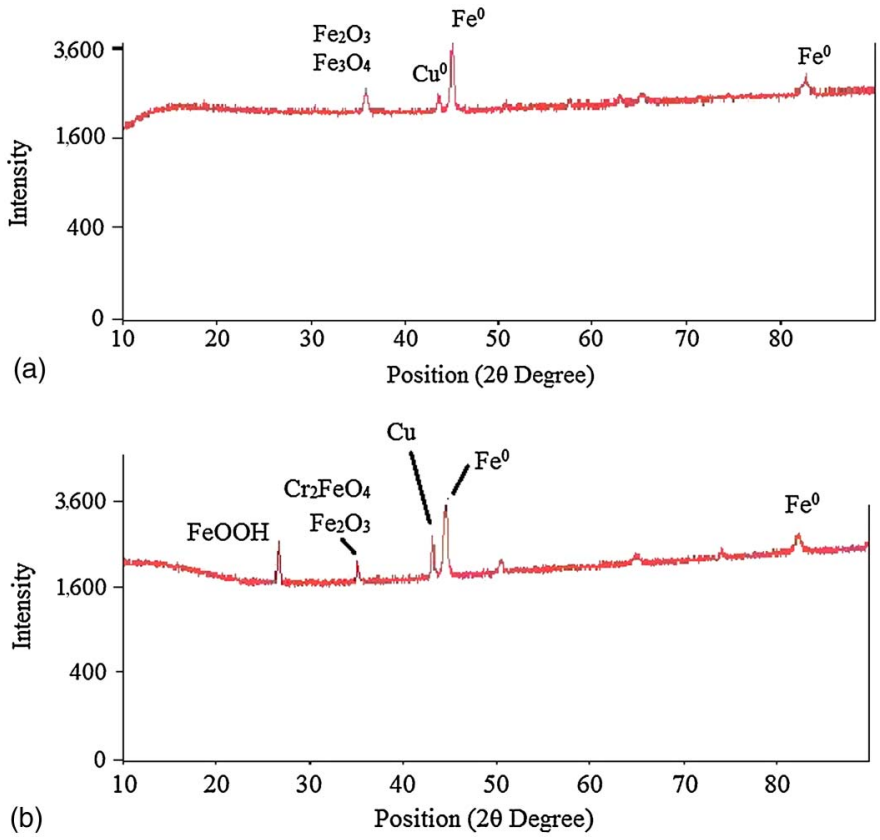

Fig. 2. XRD patterns: (a) $\mathrm{Cu}-\mathrm{ZVI}$ particles $\left(Q_{\mathrm{Cu} / \mathrm{Fe}}=8 \%\right.$ ); (b) $\mathrm{Cu}-\mathrm{ZVI}$ particles $\left(Q_{\mathrm{Cu} / \mathrm{Fe}}=8 \%\right)$ exposed to $50-\mathrm{mg} / \mathrm{L}$ chromium(VI) solution

therefore attributed to additional growth of Fe oxides consequent to $\mathrm{Fe}^{0}$ oxidation in the presence of copper.

\section{Effect of Copper Loading on Chromium(IV) Reduction}

Fig. 4 plots the mass of chromium(VI) reduced per gram of bimetallic particle as a function of time on agitating $0,1,5$, and $8 \%$ copperloaded ZVI particles with $10 \mathrm{mg} / \mathrm{L}$ nonbuffered chromium(VI) solution (solids:solution ratio $=2: 100$ ). Figs. 5 and 6 plot similar data for 30 - and $50-\mathrm{mg} / \mathrm{L}$ chromium(VI) solutions (solids:solution ratio $=2: 100$ ). At a given chromium $(\mathrm{VI})$ concentration $(10-50 \mathrm{mg} / \mathrm{L})$, the rate of chromium(VI) reduction rapidly increases up to certain period (60-240 $\mathrm{min}$ ) and thereafter reaches equilibrium, the time needed to attain equilibrium being higher for the solution with higher initial chromium(VI) concentration. Interestingly, for a given chromium(VI) concentration (Figs. 4-6), the time required to attain equilibrium is independent of the $Q_{\mathrm{Cu} / \mathrm{Fe}}$ ratio, though the mass of chromium(VI) reduced increases with this ratio at a given time period. Similar data were generated for 0.5 - and 1-g ZVI particles loaded with $0,1,5$, and $8 \%$ copper and agitated with 10-, 30-, and 50-mg/L chromium(VI) solutions; for brevity, however, the plots are not presented in this paper.

Table 2 summarizes the percent increase in chromium(VI) reduction at equilibrium (agitation period $=360 \mathrm{~min}$ ) upon copper loading with reference to unloaded ZVI particles. The data are presented for various solids:solution ratios $(0.5-2 \mathrm{~g} / 100 \mathrm{~mL})$ that were exposed to 5-, 10-, 30-, and 50-mg/L chromium(VI) solutions. The percentage increase in chromium(VI) reduction is calculated as

\section{[milligrams of chromium(VI) reduced per gram of Cu-ZVI particle]}

- [milligrams of chromium(VI) reduced per gram of ZVI particle]

$$
\times 100 \%
$$

It is shown in Table 2 that for a given chromium(VI) concentration and a given solids:solution ratio, a greater magnitude of chromium(VI) reduction is facilitated by increase in copper loading

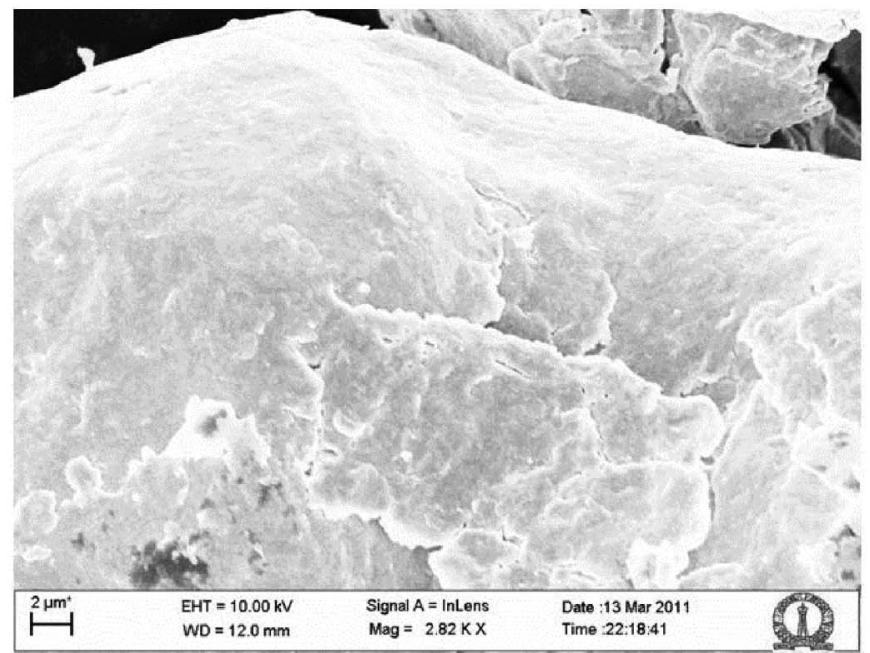

(a)

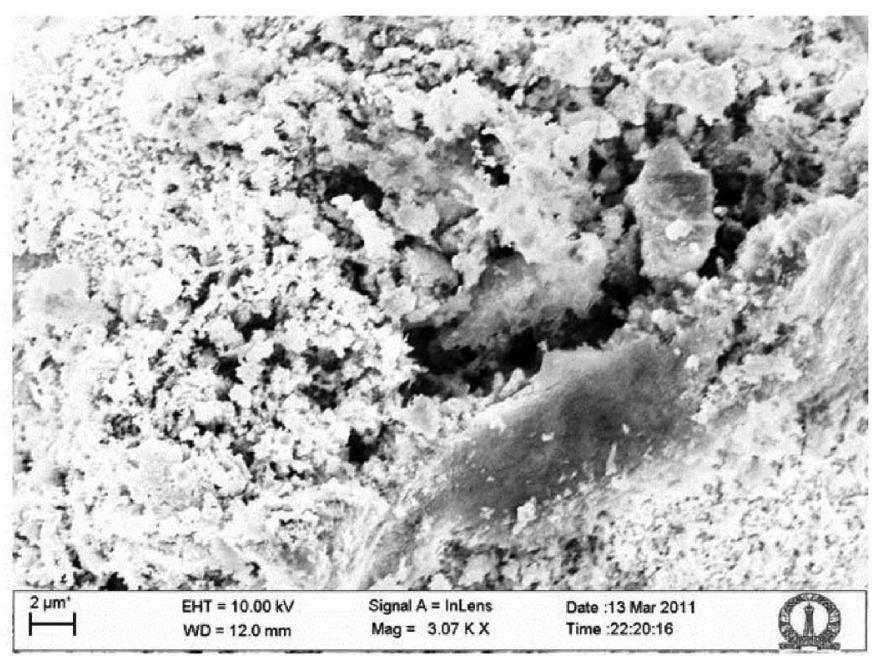

(b)

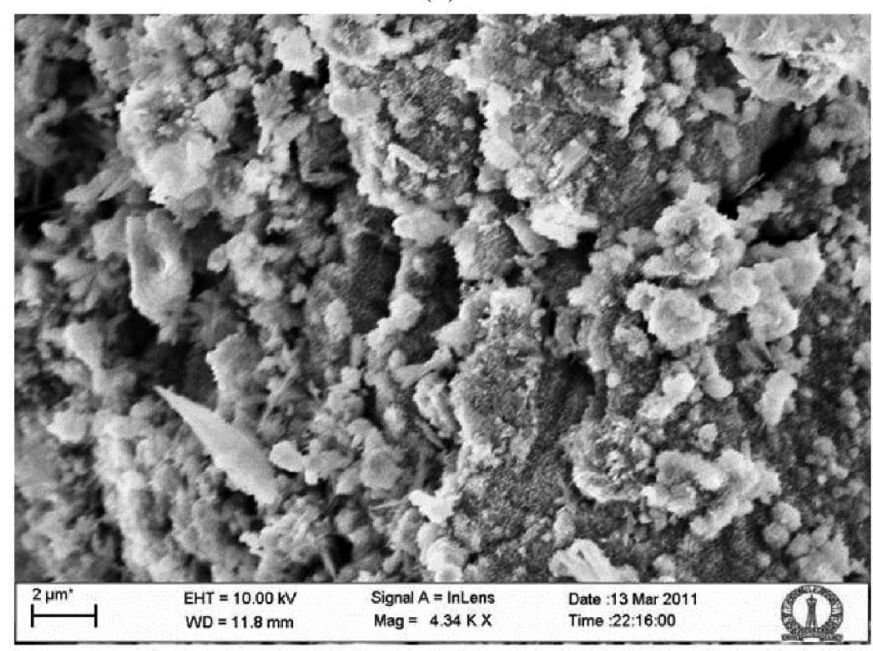

(c)

Fig. 3. Scanning electron micrographs: (a) ZVI particles; (b) $\mathrm{Cu}-\mathrm{ZVI}$ particles $\left(Q_{\mathrm{Cu} / \mathrm{Fe}}=8 \%\right)$; (c) $\mathrm{Cu}-\mathrm{ZVI}$ particles $\left(Q_{\mathrm{Cu} / \mathrm{Fe}}=8 \%\right)$ exposed to $50-\mathrm{mg} / \mathrm{L}$ chromium(VI) solution

on the ZVI particle surface. According to Bureau of Indian Standards (BIS) drinking water specification BIS 10500, the permissible limit for chromium(VI) ion concentration in drinking water is $0.05 \mathrm{mg} / \mathrm{L}$ (BIS 1991). This condition is attained only at solids:solution ratios of 2:100 $\left(Q_{\mathrm{Cu} / \mathrm{Fe}}, 1,5\right.$, and $\left.8 \%\right)$ and $1: 100$ 


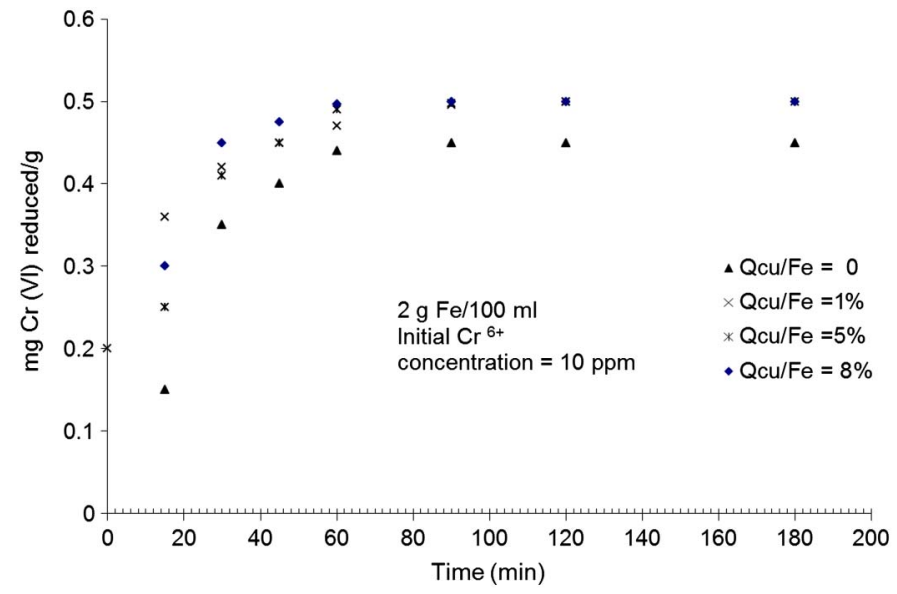

Fig. 4. Mass of chromium(VI) reduced as function of time [initial chromium $(\mathrm{VI})$ concentration $=10 \mathrm{mg} / \mathrm{L}$; solids:solution ratio $=2: 100]$

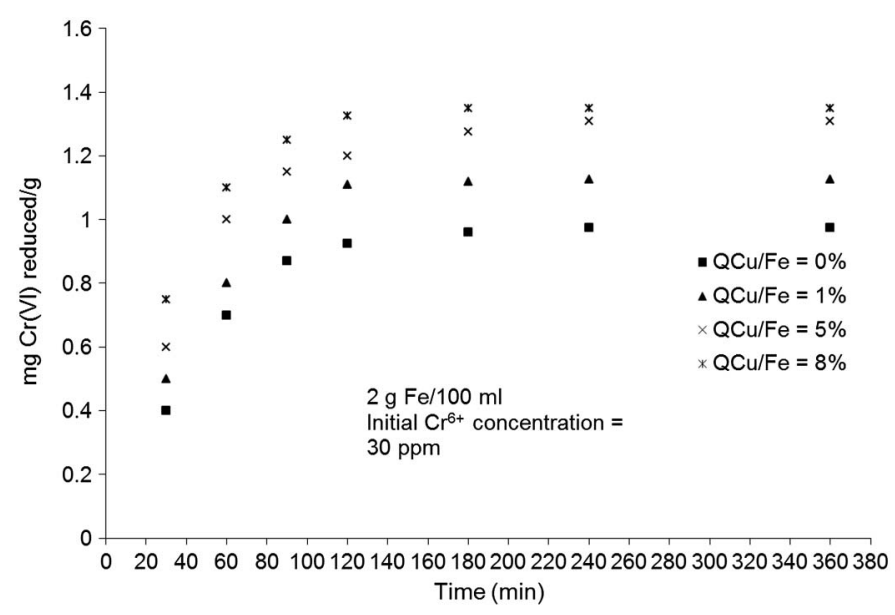

Fig. 5. Mass of chromium(VI) reduced as function of time [initial chromium $(\mathrm{VI})$ concentration $=30 \mathrm{mg} / \mathrm{L}$; solids:solution ratio $=2: 100]$

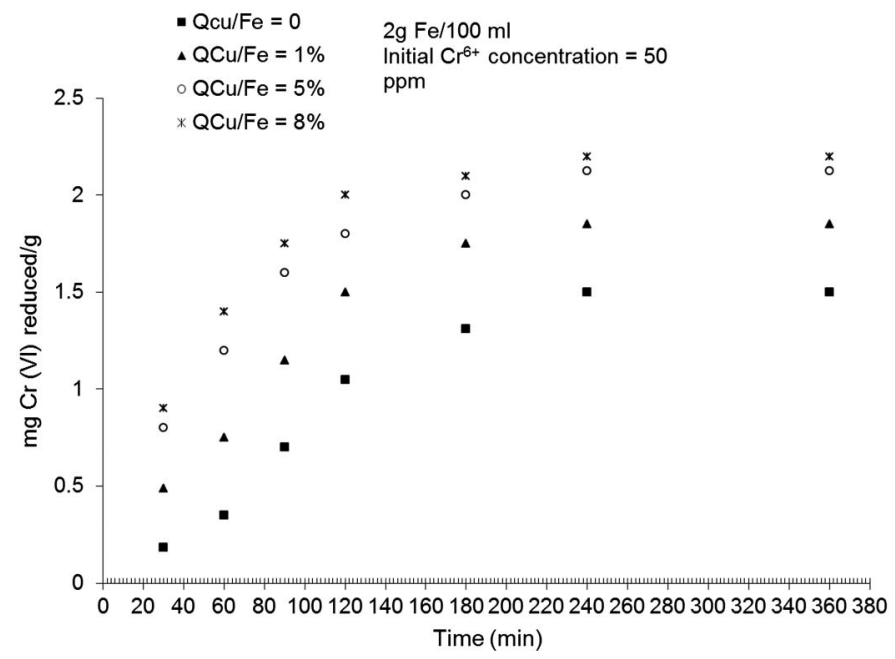

Fig. 6. Mass of chromium(VI) reduced as function of time [initial chromium $(\mathrm{VI})$ concentration $=50 \mathrm{mg} / \mathrm{L}$; solids:solution ratio $=2: 100]$
$\left(Q_{\mathrm{Cu} / \mathrm{Fe}}, 5\right.$ and $\left.8 \%\right)$ on contact with $10-\mathrm{mg} / \mathrm{L}$ chromium(VI) solution for $360 \mathrm{~min}$.

Table 2 also includes experimental results performed with buffered (with 250-mg/L bicarbonate) chromium(VI) solutions. The initial chromium(VI) $(5 \mathrm{mg} / \mathrm{L})$ and bicarbonate $(250 \mathrm{mg} / \mathrm{L})$ concentrations were guided by values reported for contaminated groundwater in an industrial locality in Bangalore, India, by Ramesh et al. (2012). These experiments were performed to simulate the groundwater chromium concentrations and to examine the influence of bicarbonate buffering on the $\mathrm{pH}$ of the treated solution (discussed subsequently). The permissible limit for chromium(VI) ion concentration in drinking water $(0.05 \mathrm{mg} / \mathrm{L})$ is attained at solids:solution ratios of 2:100 and 1:100 $\left(Q_{\mathrm{Cu} / \mathrm{Fe}}, 1,5\right.$, and $\left.8 \%\right)$ on contact with 5-mg/L chromium(VI) solution for $360 \mathrm{~min}$.

Previously, Qian et al. (2008) had observed that chromium(VI) reduction by iron powder follows pseudo first-order kinetics, and that the rate of chromium(VI) reduction increased with $\mathrm{Fe}^{0}$ addition and temperature. The kinetic parameters for pseudo first-order kinetics are derived by using a simple Lagergren equation (Ho and McKay 1999):

$$
\ln \left(q_{e}-q_{T}\right)=\ln \left(q_{e}-k_{1} T\right)
$$

where $q_{e}$ and $q_{T}=$ mass of chromium(VI) reduced per gram of bimetallic particle at equilibrium $\left(q_{e}\right)$ and time $T\left(q_{T}\right)$; and $k_{1}=$ pseudo first-order rate constant (Gupta and Bhattacharya 2005). Fig. 7 presents the pseudo first-order kinetic plots for chromium(VI) reduction from a $50-\mathrm{mg} / \mathrm{L}$ solution (solids: solution ratio $=2: 100$ ) by copper-loaded ZVI particles $\left(Q_{\mathrm{Cu} / \mathrm{Fe}}=1,5\right.$, and $\left.8 \%\right)$. All three plots exhibit high correlation coefficients $\left(R^{2}\right.$ values $\left.=0.97-0.99\right)$. Besides strong correlation coefficients, obeying pseudo first-order kinetics requires that the experimental $\ln q_{e}$ values agree with the graphical intercepts $\left(\ln q_{e}\right)$ of the $\ln \left(q_{e}-q_{T}\right)$ versus $T$ plots. Examination of the data indicates that the graphical (intercept of plot in Fig. 7) $\ln q_{e}$ agrees with the experimental values at copper loadings of 5 and $8 \%$ but deviates at copper loading of $1 \%$. The graphical $\ln q_{e}$ values at 1,5 , and $8 \%$ loading correspond to $0.61,0.75$, and 0.79 , respectively, whereas the experimental $\ln q_{e}$ values at similar copper loadings correspond to $1.07,0.81$, and 0.79 , respectively.

When chromium(VI) reduction does not follow pseudo firstorder kinetics, pseudo second-order kinetics may be assumed (Gupta and Bhattacharya 2005; Ho et al. 2001):

$$
T / q_{T}=1 / h+\left(1 / q_{e}\right) \cdot T
$$

where $h=k_{2} q_{e}^{2}$; and $k_{2}=$ pseudo second-order rate constant. Fig. 8 presents the pseudo second-order rate plot for chromium(VI) reduction (initial solution concentration $=50 \mathrm{mg} / \mathrm{L}$ ) by copper-loaded ZVI particles $\left(Q_{\mathrm{Cu} / \mathrm{Fe}}=1 \%\right.$, and solids:solution ratio $\left.=2: 100\right)$. A linear form of the plot results $\left(R^{2}=0.95\right)$; the graphical $q_{e}$ value (1/slope) of 2.56 is in excess of the experimental value (1.85).

\section{Variations in $\mathrm{pH}$ and $\mathrm{Eh}$}

Tables 3 and 4 present the changes in $\mathrm{pH}$ and $\mathrm{Eh}$ (redox potential) experienced by ZVI and copper-loaded ZVI particles on equilibration with nonbuffered and buffered (with $250-\mathrm{mg} / \mathrm{L}$ bicarbonate) chromium(VI) solutions for $360 \mathrm{~min}$. An increase in $\mathrm{pH}$ and a decrease in Eh are noted at all solids:solution ratios, implying enhanced electron activity and release of hydroxyl ions from net corrosion reaction of the type (Powell et al. 1995)

$$
\mathrm{Fe}^{0}+\mathrm{CrO}_{4}^{2-}+4 \mathrm{H}_{2} \mathrm{O} \leftarrow \rightarrow \mathrm{Fe}(\mathrm{OH})_{3}+\mathrm{Cr}(\mathrm{OH})_{3}+2 \mathrm{OH}^{-}
$$

Further, at a given solids:solution ratio and initial chromium concentration, an increase in copper loading promotes lower Eh and higher $\mathrm{pH}$, implying a stronger corrosion reaction. Copper does 
Table 2. Percent Increase in Chromium(VI) Reduction from Copper Loading of ZVI Particles

\begin{tabular}{|c|c|c|c|c|c|c|c|}
\hline \multirow[b]{2}{*}{$\begin{array}{l}\text { Initial Cr } \\
(\mathrm{mg} / \mathrm{L})\end{array}$} & \multirow[b]{2}{*}{$\begin{array}{c}Q_{\mathrm{Cu} / \mathrm{Fe}} \\
\text { (percentage) }\end{array}$} & \multicolumn{2}{|c|}{$2 \mathrm{~g} / 100 \mathrm{~mL}$} & \multicolumn{2}{|c|}{$1 \mathrm{~g} / 100 \mathrm{~mL}$} & \multicolumn{2}{|c|}{$0.5 \mathrm{~g} / 100 \mathrm{~mL}$} \\
\hline & & $\begin{array}{l}\text { Percentage increase } \\
\text { in chromium(VI) } \\
\text { reduction }\end{array}$ & $\begin{array}{c}\text { Residual } \\
\text { chromium(VI) } \\
\text { concentration } \\
(\mathrm{mg} / \mathrm{L})\end{array}$ & $\begin{array}{l}\text { Percentage increase } \\
\text { in chromium(VI) } \\
\text { reduction }\end{array}$ & $\begin{array}{c}\text { Residual } \\
\text { chromium(VI) } \\
\text { concentration, } \\
(\mathrm{mg} / \mathrm{L})\end{array}$ & $\begin{array}{l}\text { Percentage increase } \\
\text { in chromium(VI) } \\
\text { reduction }\end{array}$ & $\begin{array}{c}\text { Residual } \\
\text { chromium(VI) } \\
\text { concentration } \\
(\mathrm{mg} / \mathrm{L})\end{array}$ \\
\hline \multicolumn{8}{|c|}{ Nonbuffered chromium(VI) solutions } \\
\hline \multirow[t]{3}{*}{50} & 1 & 23 & 13 & 50 & 20 & 167 & 30 \\
\hline & 5 & 42 & 7.5 & 75 & 15 & 233 & 25 \\
\hline & 8 & 47 & 6 & 80 & 14 & 233 & 23.8 \\
\hline \multirow[t]{3}{*}{30} & 1 & 15 & 7.5 & 39 & 10 & 75 & 16 \\
\hline & 5 & 34 & 3.8 & 53 & 8 & 100 & 14 \\
\hline & 8 & 38 & 3 & 60 & 7 & 106 & 13.5 \\
\hline \multirow[t]{3}{*}{10} & 1 & 11 & 0.004 & 29 & 1 & 25 & 5 \\
\hline & 5 & 11 & 0.004 & 42 & 0.04 & 70 & 3.2 \\
\hline & 8 & 11 & 0.004 & 43 & 0.02 & 75 & 3 \\
\hline \multicolumn{8}{|c|}{ Bicarbonate buffered chromium(VI) solution } \\
\hline \multirow[t]{3}{*}{5} & 1 & 0 & 0.04 & 4.2 & 0.049 & 5.6 & 0.068 \\
\hline & 5 & 0 & 0.04 & 4.3 & 0.046 & 5.5 & 0.054 \\
\hline & 8 & 0 & 0.04 & 4.4 & 0.042 & 5.5 & 0.054 \\
\hline
\end{tabular}

not form oxides, as indicated by the presence of the $\mathrm{Cu}^{0}$ peak $\left(2 \theta=43.7^{\circ}\right)$ in Fig. 2(b). The XRD pattern in Fig. 2(b) corresponds to $\mathrm{Cu}-\mathrm{ZVI}$ particles $\left(Q_{\mathrm{Cu} / \mathrm{Fe}}=8 \%\right)$ that were exposed to $50-\mathrm{mg} / \mathrm{L}$

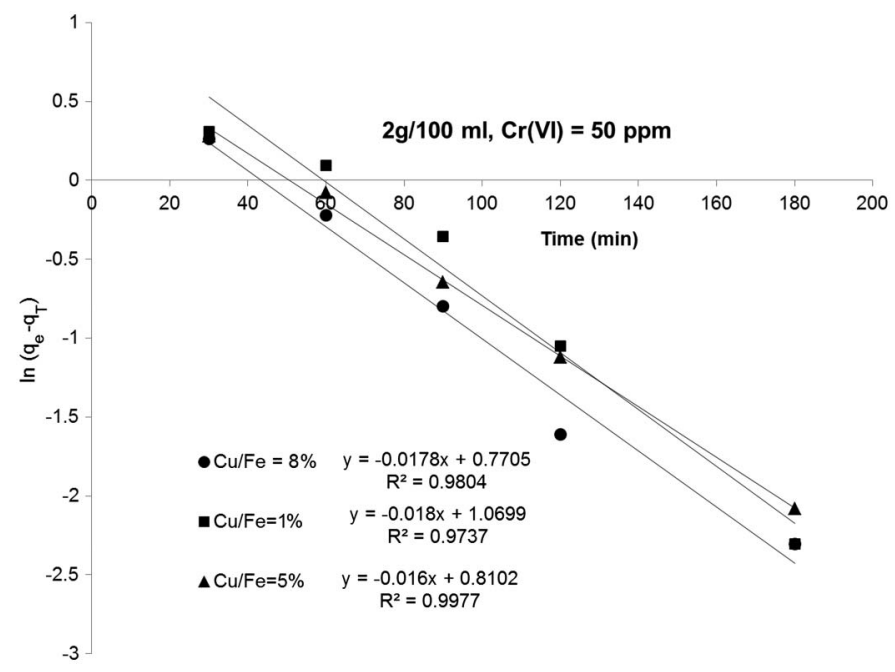

Fig. 7. Pseudo first-order plots for chromium(VI) reduction [initial chromium $(\mathrm{VI})$ concentration $=50 \mathrm{mg} / \mathrm{L}$; solids:solution ratio $=2: 100]$

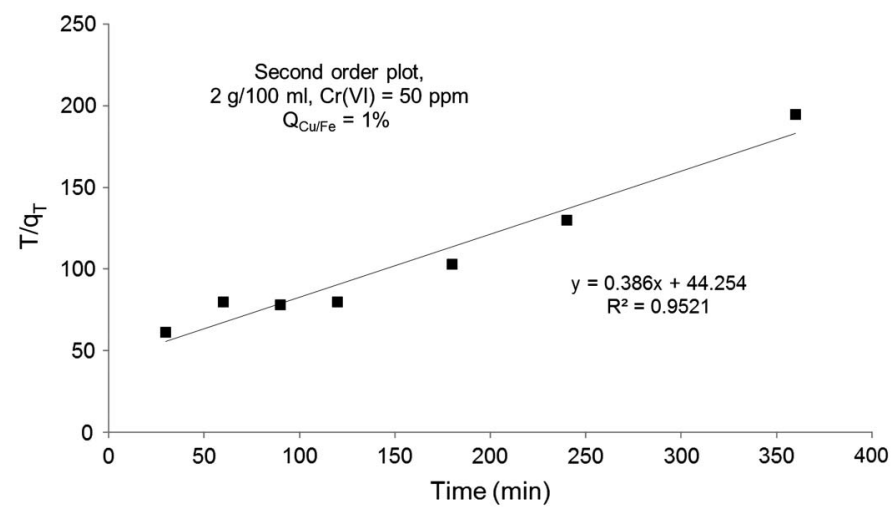

Fig. 8. Pseudo second-order plots for chromium(VI) reduction [initial chromium $(\mathrm{VI})$ concentration $=50 \mathrm{mg} / \mathrm{L}$; solids:solution ratio $=2: 100]$
chromium(VI) solution. Besides reflections for $\mathrm{Fe}^{0}$ and $\mathrm{Cu}^{0}$, peaks at $2 \theta=26.72$ and $35.5^{\circ}$ were observed. The peak at $26.72^{\circ}$ is ascribed to $\mathrm{FeOOH}$, whereas the peak at $35.5^{\circ}$ is ascribed to $\mathrm{Fe}_{2} \mathrm{O}_{3}(\mathrm{~s})$ and $\mathrm{Cr}_{2} \mathrm{FeO}_{4}(\mathrm{~s})$, respectively. The synthetic chromite $\left(\mathrm{Cr}_{2} \mathrm{FeO}_{4}\right)$ is formed according to the reaction

$$
\mathrm{Fe}^{2+}+2 \mathrm{Cr}^{3+}+4 \mathrm{H}_{2} \mathrm{O} \quad \mathrm{Cr}_{2} \mathrm{FeO}_{4}+8 \mathrm{H}^{+}
$$

The scanning electron micrograph [Fig. 3(c)] of $\mathrm{Cu}-\mathrm{ZVI}$ particles $\left(Q_{\mathrm{Cu} / \mathrm{Fe}}=8 \%\right)$ exposed to $50-\mathrm{mg} / \mathrm{L}$ chromium(VI) solution shows deposition of discrete precipitates that are possibly the mixed $\mathrm{Cr}-\mathrm{Fe}$ oxide identified earlier in the XRD pattern [Fig. 2(b)]. Similar trend of results were observed at lower chromium(VI) concentrations $(10$ and $30 \mathrm{mg} / \mathrm{L})$; for brevity, the results are not presented in this paper.

Table 3 reveals that the $\mathrm{pH}$ of the $50-\mathrm{mg} / \mathrm{L}$ chromium(VI) solution markedly increased from 4.36 to $7-10.8$ on equilibration with $\mathrm{Cu}-\mathrm{ZVI}$ particles, apparently because of the absence of the buffering influence of bicarbonates that are encountered in groundwater. The role of bicarbonates is demonstrated from results obtained with

Table 3. $\mathrm{pH}$ and Eh Values of Nonbuffered Chromium(VI) Solution before and after Equilibration with $\mathrm{Cu}-\mathrm{ZVI}$ Particles

\begin{tabular}{|c|c|c|c|c|}
\hline $\begin{array}{l}Q_{\mathrm{Cu} / \mathrm{Fe}} \\
\text { (percentage) }\end{array}$ & Initial $\mathrm{pH}$ & Final $\mathrm{pH}$ & $\begin{array}{c}\text { Initial Eh } \\
(\mathrm{mV})\end{array}$ & $\begin{array}{c}\text { Final Eh } \\
(\mathrm{mV})\end{array}$ \\
\hline \multicolumn{5}{|c|}{ ZVI or bimetal content $=2 \mathrm{~g} / 100 \mathrm{~mL}$} \\
\hline 8 & 4.36 & 10.8 & 578.8 & 464.2 \\
\hline 5 & & 10.4 & & 468.5 \\
\hline 1 & & 8.5 & & 478.3 \\
\hline 0 & & 7.6 & & 483.8 \\
\hline \multicolumn{5}{|c|}{$\mathrm{ZVI}$ or bimetal content $=1 \mathrm{~g} / 100 \mathrm{~mL}$} \\
\hline 8 & 4.36 & 9.8 & 578.8 & 470.5 \\
\hline 5 & & 9.6 & & 472.0 \\
\hline 1 & & 7.8 & & 486.0 \\
\hline 0 & & 7.2 & & 490.2 \\
\hline \multicolumn{5}{|c|}{ ZVI or bimetal content $=0.5 \mathrm{~g} / 100 \mathrm{~mL}$} \\
\hline 8 & 4.36 & 7.8 & 578.8 & 488.7 \\
\hline 5 & & 7.6 & & 488.0 \\
\hline 1 & & 7.0 & & 502.6 \\
\hline 0 & & 6.8 & & 518.7 \\
\hline
\end{tabular}

Note: Initial concentration of nonbuffered chromium(VI) solution $=$ $50 \mathrm{mg} / \mathrm{L}$. 
Table 4. $\mathrm{pH}$ and Eh Values of Bicarbonate $(250 \mathrm{mg} / \mathrm{L})$ Buffered Chromium(VI) Solution before and after Equilibration with $\mathrm{Cu}-\mathrm{ZVI}$ Particles

\begin{tabular}{|c|c|c|c|c|}
\hline $\begin{array}{l}Q_{\mathrm{Cu} / \mathrm{Fe}} \\
\text { (percentage) }\end{array}$ & Initial $\mathrm{pH}$ & Final $\mathrm{pH}$ & $\begin{array}{l}\text { Initial Eh } \\
\quad(\mathrm{mV})\end{array}$ & $\begin{array}{c}\text { Final El } \\
(\mathrm{mV})\end{array}$ \\
\hline \multicolumn{5}{|c|}{ ZVI or bimetal content $=0.5 \mathrm{~g} / 100 \mathrm{~mL}$} \\
\hline 8 & 7.9 & 8.75 & 717 & 191 \\
\hline 5 & & 7.52 & & 336 \\
\hline 1 & & 7.89 & & 230 \\
\hline 0 & & 9.62 & & 179 \\
\hline \multicolumn{5}{|c|}{$\mathrm{ZVI}$ or bimetal content $=1 \mathrm{~g} / 100 \mathrm{~mL}$} \\
\hline 8 & 7.9 & 8.2 & 717 & 199 \\
\hline 5 & & 8 & & 137 \\
\hline 1 & & 7.5 & & 193 \\
\hline 0 & & 9.69 & & 162 \\
\hline \multicolumn{5}{|c|}{ ZVI or bimetal content $=2 \mathrm{~g} / 100 \mathrm{~mL}$} \\
\hline 8 & 7.9 & 9.1 & 717 & 27 \\
\hline 5 & & 9.25 & & 95 \\
\hline 1 & & 8.9 & & 166 \\
\hline 0 & & 9.67 & & 158 \\
\hline
\end{tabular}

Note: Initial concentration of bicarbonate buffered chromium(VI) solution $=5 \mathrm{mg} / \mathrm{L}$.

bicarbonate buffered chromium(VI) solutions (Table 4); the pH of the buffered solutions varies between a narrower range of 7.5 and 9.7 after contact with $\mathrm{Cu}-\mathrm{ZVI}$ particles (initial value $=7.9$ ).

\section{Conclusions}

Deposition of 1-8\% of copper on the surface of ZVI particles enhances chromium(VI) reduction by $11-233 \%$ owing to stronger corrosion of ZVI particles, as evidenced by the lower Eh and higher $\mathrm{pH}$ values. The enhanced electron activity and release of hydroxyl ions converted chromium(VI) to mixed $\mathrm{Fe}-\mathrm{Cr}$ oxide, supported by $\mathrm{X}$-ray diffraction and scanning electron micrograph studies. The chromium(VI) reduction was accomplished in periods ranging from 60-240 min in the batch experiments. Chromium(VI) reduction obeyed the pseudo first-order kinetics at copper loadings of 5 and $8 \%$ and pseudo second-order kinetics at copper loading of $1 \%$ [initial chromium $(\mathrm{VI})$ concentration $=50 \mathrm{mg} / \mathrm{L}$ ]. The copperloaded ZVI particles were able to lower chromium(VI) levels to drinking water limits $(\leq 0.05 \mathrm{mg} / \mathrm{L})$ only when the initial concentration corresponded to $10 \mathrm{mg} / \mathrm{L}$ and a minimum solids:solution ratio of 1:100 was used. The residual chromium(VI) levels were 20-400 times higher than the permissible chromium(VI) limit in drinking water when 30 - and 50-mg/L chromium(VI) solutions were used in the batch experiments (solids:solution ratio $=1-2 \mathrm{~g} / 100 \mathrm{~mL}$ ). Buffering with bicarbonates caused narrower variations in $\mathrm{pH}$ of treated solutions in comparison with nonbuffered solutions.

\section{References}

Alowitz, M. J., and Scherer, M. M. (2002). "Kinetics of nitrate, nitrite and Cr(VI) reduction by iron metal.” Environ. Sci. Technol., 36, 299-306.

Barceloux, D. G., and Barceloux, D. (1999). "Chromium." Clin. Toxicol., 37, 173-194.

Blowes, D. W., et al. (1999). "An in situ permeable reactive barrier for the treatment of hexavalent chromium and trichloroethylene in ground water. Volume 1: Design and installation." EPA/600/R-99/095a, U.S. EPA, Washington, DC.

Blowes, D. W., Ptacek, C. J., and Jambor, J. L. (1997). "In-situ remediation of $\mathrm{Cr}(\mathrm{VI})$ contaminated groundwater using permeable reactive walls: laboratory studies." Environ. Sci. Technol., 31, 3348-3357.
Bureau of Indian Standards (BIS). (1991). "Drinking water specification." BIS 10500, New Delhi, India.

Cheng, I. F., Fernando, Q., and Korte, N. (1997). "Electro-chemical dechlorination of 4-chlorophenol to phenol." Environ. Sci. Technol., 31, 1074-1078.

Eary, L. E., and Rai, D. (1988). "Chromate removal from aqueous wastes by reduction with ferrous iron." Environ. Sci. Technol., 22, 972-977.

Erdem, M., Gur, F., and Tuman, F. (2004). "Cr(VI) reduction in aqueous solution by siderite." J. Hazard. Mater. B, 113(1-3), 217-222.

Grittini, C., Malcomson, M., Fernando, Q., and Korte, N. (1995). "Rapid dechlorination of polychlorinated biphenyls on the surface of $\mathrm{Pd} / \mathrm{Fe}$ bimetallic system." Environ. Sci. Technol., 29, 2898-2900.

Gui, L., Yang, Y., Jeen, S. W., Gillham, R. W., and Blowes, D. W. (2009). "Reduction of chromate by granular iron in the presence of dissolved CaCO3." Appl. Geochem., 24, 677-686.

Gupta, S. S., and Bhattacharya, K. G. (2005). "Interaction of metal ions with clays: I. A case study with Pb(II).” Appl. Clay Sci., 30, 199-208.

Ho, Y. S., and McKay, G. (1999). "The sorption of lead (II) ions on peat." Water Res., 33, 578-584.

Ho, Y. S., Ng, J. C. Y., and McKay, G. (2001). "Removal of lead (II) from effluents by sorption on peats using second order kinetics." Sep. Sci. Technol., 36, 241-261.

Hu, C. Y., Lo, S. L., Liou, Y. H., Hsu, Y. W., Shih, K., and Lin, C. J. (2010). "Hexavalent chromium removal from near natural water by copperIron bimetallic particles." Water Res., 44, 3101-3108.

Jacobs, J. A., and Testa, S. M. (2005). "Overview of chromium (VI) in the environment: Background and history." Chromium (VI) Handbook, J. Guertin, J. A. Jacobs, and C. P. Avakian, eds., CRC, Boca Raton, FL.

Kim, Y. H., and Carraway, E. R. (2000). "Dechlorination of pentachlorophenol by zero valent iron and modified zero valent iron." Environ. Sci. Technol., 34, 2014-2017.

Lin, C. J., Lo, S. L., and Liou, Y. H. (2004). "Dechlorination of trichloroethylene in aqueous solution by noble metal-Modified iron." J. Hazard. Mater., 116, 219-228.

Liou, Y. H., Lo, S. L., Lin, C. J., Hu, C. Y., Kuan, W. H., and Weng, S. C. (2005). "Methods for accelerating nitrate reduction using zero-valent iron at near-neutral $\mathrm{pH}$ : Effects of $\mathrm{H}_{2}$-reducing pretreatment and copper deposition.” Environ. Sci. Technol., 39, 9643-9648.

Lo, I. M. C., Lam, C. S. C., and Lai, K. C. K. (2006). "Hardness and carbonate effects on the reactivity of zero-valent iron for $\mathrm{Cr}(\mathrm{VI})$ removal." Water Res., 40, 595-605.

Melitas, N. T., and Farrell, J. (2002). "Understanding chromate reaction kinetics with corroding iron media using Tafel analysis and electrochemical impedance spectroscopy." Environ. Sci. Technol., 36, 5476-5482.

Muftikian, R., Fernando, Q., and Korte, N. (1995). "A method for rapid dechlorination of low molecular weight chlorinated hydrocarbons in water." Water Res., 29, 2434-2439.

Palmer, C. D., and Puls, R. W. (1994). "Natural attenuation of hexavalent chromium in groundwater and soils." EPA/540/5-94/505, U.S. EPA, Washington, DC.

Powell, R. M., Puls, R. W., Hightower, S. K., and Sabatini, D. A. (1995). "Coupled iron corrosion and chromate reduction: Mechanisms for subsurface remediation." Environ. Sci. Technol., 29, 1913-1922.

Proctor, D. M., Shay, E. C., and Scott, P. K. (1997). "Health-based soil action levels for trivalent and hexavalent chromium: A comparison with state and federal standards." J. Soil Contam., 6, 595-648.

Puls, R. W., Blowes, D. W., and Gillham, R. W. (1999). "Long-term performance monitoring for a permeable reactive barrier at the U.S. Coast Guard Support Center, Elizabeth City, North Carolina." J. Hazard. Mater., 68, 109-124.

Qian, H., Wu, Y., Liu, Y., and Xu, X. (2008). "Kinetics of hexavalent chromium reduction by iron metal." Front. Environ. Sci. Eng. China, 2, 51-56.

Rai, D., Sass, B. M., and Moore, D. A. (1987). "Chromium(III) hydrolysis constants and solubility of chromium(III) hydroxide." Inorg. Chem., 26, 345-349.

Ramesh, R., Nagendra Prakash, B. S., Sivapullaiaih, P. V., and Sadhashivaiah, A. S. (2012). "Assessment of ground water quality in designated Peenya Industrial Area and Estate, Bangalore, India: A case study." Int. J. Environ. Prot., 2, 21-25. 